\title{
In vitro evaluation of Mucuna pruriens (L.) DC. antioxidant activity
}

\author{
Joy Ganem Longhi', Elisa Perez ${ }^{2}$, Jair José de Lima³ ${ }^{3}$ Lys Mary Bileski Cândido,4,** \\ ${ }^{1}$ Pharmacy Department (PPGCF), Federal University of Paraná, ${ }^{2}$ Chemistry Department , Federal University of Paraná, \\ ${ }^{3}$ Nutrition Department, Federal University of Paraná, ${ }^{4}$ Food Coordination, Technological Federal University of Paraná
}

\begin{abstract}
Mucuna pruriens (L). Dc is a plant of the Fabaceae family, commonly known as velvet bean, itchy bean, chiporro bean, mucuna, among others. This plant has several medicinal properties, including its potential to treat Parkinson's disease (PD). International studies have shown that this plant surpasses the benefits of the substance levodopa in the treatment of PD. Taking into account that nerve cells are highly sensitive to oxidative substances, this study evaluated the antioxidant activity of mucuna and compared it to that of levodopa. The plant seeds' phenolic concentration was quantified by using the Folin-Denis reagent and the antioxidant activity assays were performed by using three different methods: the reduction of the phosphomolybdenium complex, the reduction of radical 1,1-diphenyl-2-picrylhydrazyl (DPPH') and the formation of radical monocation $\mathrm{ABTS}^{+}$, from the acid [2-2'-azinobis (3-ethylbenzothiazoline-6sulfonate)]. Results showed that $M$. pruriens presents high antioxidant capacity, although not superior to isolated levodopa antioxidant capacity. Therefore, further studies should be performed to elucidate the activity of this plant in humans.
\end{abstract}

Uniterms: Mucuna pruriens. Antioxidant. Phenolic compounds

\begin{abstract}
A Mucuna pruriens (L). Dc é uma planta da família Fabaceae, conhecida popularmente como feijãoveludo, fava-coceira, feijão chiporro, mucuna, entre outros. Possui diversas propriedades medicinais, entre elas, o tratamento da doença de Parkinson (DP). Estudos internacionais vêm demonstrando que essa planta possui atividade superior à do fármaco levodopa para o tratamento da DP. O presente estudo avaliou a possibilidade da atividade antioxidante dessa planta auxiliar nesses resultados, uma vez que as células nervosas são altamente sensíveis às substâncias oxidativas. Para isto foi quantificada a concentração fenólica da semente da mucuna e os testes empregados para a avaliação da atividade antioxidante foram o teste de redução do complexo fosfomolibdênio, redução do radical 1,1-difenil-2-picril-hidrazil (DPPH') e a formação do radical monocatiônico $\mathrm{ABTS}^{++}$, proveniente do ácido [2-2' -azino-bis(3-etil-benzolina-6sulfonado)]. Essa análise demonstrou que $M$. pruriens possui alta capacidade antioxidante, no entanto, não superior à levodopa isolada e, portanto, novos estudos devem ser realizados para a elucidação da atividade dessa planta em seres humanos.
\end{abstract}

Unitermos: Mucuna pruriens. Antioxidante. Compostos fenólicos.

\section{INTRODUCTION}

Mucuna pruriens (L). Dc is a plant of the Fabaceae family (Rajeshwar et al., 2005), typically found in tropical regions and used for various purposes in traditional medicine in several countries. In India and West Africa for example, it is used against snake bites (Siddhuraju, Vijayakumari, Janardhanan, 1996; Aguyi et al., 1999, Chikagwa-Malunga et al., 2009). It is also used as a uterine

*Correspondence: L. M. B. Cândido. Coordenação do Curso de Tecnologia em Alimentos (COALM), Universidade Tecnológica Federal do Paraná,. Caixa Postal 135 - 85.601-971 - Francisco Beltrão - PR, Brasil. E-mail para contato: lysmary@ufpr.br,1mcandido@utfpr.edu.br stimulant and aphrodisiac (Amin et al., 1996). In Honduras, Central America, Africa and Guinea, this plant is also used as food (Diallo et al., 2002).

All parts of the mucuna plant possess medicinal properties (Sathiyanarayanan; Arulmozhi, 2007). It is known that the main phenolic compound of the mucuna seeds is levodopa (approximately 5\%) (Vadivel; Pugalenthi, 2008; Chikagwa-Malunga et al., 2009). Nowadays, mucuna is widely studied because levodopa is a substance used as first-line treatment of Parkinson's disease (PD). Some studies indicate that Mucuna pruriens has many advantages over synthetic levodopa when administered to patients with PD, since synthetic levodopa presents 
several side effects when used for many years (Tharakan et al., 2007).

In small amounts (approximately $0.25 \%$ ) levodopa corresponds to the methylated and non-methylated tetra hydroisoquinoline (Manyam, 1990; Siddhuraju, Becker, 2001). These substances are present in the mucuna roots, stems, leaves and seeds (Szabo, Tebbett, 2002). Other substances are present in different parts of the plant, among them nicotine, physostigmine, serotonin, bufotenine, choline (Kavitha, Vadivel, 2007), N, N - dimethyl - tryptamine and some indole compounds (Tripathi, Upadhyay, 2001; Chikagwa-Malunga et al., 2009).

Some grains in nature present medicinal properties due to the presence of phenolic constituents usually associated with an antioxidant activity (Krishnaiah, Sarbatly, Nithyanandam, 2010). Among the phenolic compounds present in plants, the most active and frequently observed are the flavonoids and the phenolic acids (Broinizi et al., 2007).

Reactive oxygen species (ROS) are free radicals formed during cellular metabolism (Valko et al., 2006). The oxygen-derived radicals represent the most important class among the free radicals formed in living organisms (Miller, Buettner, Aust, 1990). More than 45 diseases are known to be mediated by free radicals (Tripathi, Upadhyay, 2002). Recently, a number of clinical studies on neurodegenerative diseases, including Parkinson's disease, have dealt with the assessment of antioxidant activity of several substances.

The brain is extremely sensitive to free radicals. The abundance of polyunsaturated fatty acids facilitates prooxidant processes (Póvoa Filho, 1995), since peroxidation of these acids impairs the normal function of cell membrane and receptors, which results in protein denaturation, leading to enzyme inactivation and damage to the linking bridges of DNA (Rogers et al., 2000). Other contributing factors for the above-mentioned processes are high iron content, low level of chelating agents and the lack of antioxidants in this region of the cells (Póvoa Filho, 1995)

Current studies have evaluated the use of natural products for treating PD. It is believed that the chemical derivatives and the synthetic analogues of natural products may have a unique connection to specific receptors in the treatment of the disease (Houghton, Howes, 2005).

Dopaminergic anti-parkinsonian medications, such as levodopa (LD) cause drug-induced dyskinesias (DID) in the majority of patients with Parkinson's disease (PD). Mucuna pruriens, a legume extensively used in Ayurveda to treat PD, is reputed to provide anti-parkinsonian benefits without inducing DID (Lieu et al., 2010). Hussian and Manyam (1997) stated that the seeds of M. pruriens are two to three times more effective than levodopa in controlling the symptoms of PD. In addition, levodopa causes many adverse effects (Dhanasekaran, Tharakan, Manyam, 2008). According to Manyam, Dhanasekaran and Hare (2004), M. pruriens has a significant neuroprotective effect and restores the levels of dopamine in the substantia nigra and of norepinephrine in the nigrostriatal system of animal models.

Some studies, conducted mostly in India, have demonstrated that the use of $M$. pruriens has a positive effect in the treatment of Parkinson's disease, which is superior to the treatment carried out with levodopa. Such discoveries stimulated us to conduct this research. The maturer whole plant presents a higher concentration of L-dopa due to development of pods, which contain more L-dopa than other plant parts. M. pruriens seeds had an average L-dopa concentration of $48.9 \mathrm{~g} / \mathrm{kg}$, which is also within the range of 40-60 g/kg (Chikagwa-Malunga et al., 2009). Due to the high concentration of phenolic compounds, it is expected that $M$. pruriens seeds have high antioxidant capacity.

Such discoveries stimulated us to conduct this research. Therefore, the main objective of this study was to compare the antioxidant activity of $M$. pruriens seed extracts to that of synthetic levodopa, in a bid to shed light on the reason why the plant has significant activity in patients with Parkinson's disease.

\section{MATERIAL AND METHODS}

The exsiccate of Mucuna pruriens is deposited at the Municipal Botanical Museum of Curitiba (Herbarium 340318). The preparation of the extract was based in the patent established by Dow (1966), with some modifications. Four extractions were performed with $200 \mathrm{~g}$ of black seed of pulverized M. pruriens, provided by the Agronomic Institute of Paraná (IAPAR) and processed by the Steviafarma company. The extraction media for each extraction was composed of $600 \mathrm{~mL}$ of distilled and nitrogenated water, which was homogenized with the raw material. Gradually, citric acid (Sigma-Aldrich, St. Louis, USA) was added so that the medium $\mathrm{pH}$ was kept between 3.0 and 4.0. This measurement was performed with a digital $\mathrm{pH}$ meter at an average temperature of $23^{\circ} \mathrm{C}$. Once homogenized, the mixture was filtered through a filter of polyester synthetic fabric. The filtered liquid was subjected to further filtration through a Kitasato flask, along with vacuum filtering with Inlab type 50 double filter paper. For each new extraction, the mixture of powder and deionized water was placed in an ultrasound device (Unique, model Maxiclean 750, Indaiatuba, Brazil) at a frequency of $25 \mathrm{kHz}$ for 10 minutes. After the fourth extraction all the filtrates were collected and filtered again using What- 
man 42 paper. The extract was frozen at $-18^{\circ} \mathrm{C}$ and then freeze-dried on the proper equipment (Liobras, model L101, São Carlos, Brazil). All essays using this extract were performed in triplicate.

The concentration of levodopa was quantified by high-efficiency liquid chromatography on a Varian 9012Q chromatographic device (Agilent Technologies Brasil, Barueri, Brazil) equipped with an ultraviolet photodiode array detector model 9065 and automatic injector model AI 200. The analysis was carried out in a reversed phase column (Varian Res Elut $\mathrm{C}_{18}, 5 \mu \mathrm{m}$, pore size of $90 \AA$, internal diameter of $4.6 \mathrm{~mm}$ and length of $150 \mathrm{~mm}$, made of stainless steel), at room temperature using HPLC grade methanol-Milli Q water at a 20:80 (v/v) ratio, respectively, as mobile phase. The injection volume was $20 \mu \mathrm{L}$, detection was carried out at $282 \mathrm{~nm}$ with a chromatographic run of 5 minutes and a flux of $1 \mathrm{~mL} \cdot \mathrm{min}^{-1}$ at $25^{\circ} \mathrm{C}$. For the analysis, the extract was diluted in bidistilled water, at a concentration of $4 \mathrm{mg} / \mathrm{mL}$, and centrifuged in an Avanti J-25 centrifuge (Beckman Coulter, Brea, USA) at $10,000 \mathrm{rpm}$ for 10 minutes.

The total phenolic content was measured by the method described by Swain and Hillis (1959), which uses the Folin-Denis reagent and is based on the reduction of phosphomolybdic-phosphotungstic acid by the phenolic compounds in a basic medium. The reaction produces a strong bluish color which is measured on a spectrophotometer (Femto UV, Vis, model 482, São Paulo, Brazil). For quantifying the phenolic content of the extract, a $1 \%(\mathrm{w} / \mathrm{v})$ tannic acid solution was prepared. The standard curve was built from growing concentration tannic acid (from 0.2 to $1.0 \mathrm{mg}$ ). In a $100 \mathrm{~mL}$ volumetric flask were added $5 \mathrm{~mL}$ of the reagent Folin-Denis, $10 \mathrm{~mL}$ of sodium carbonate, and water in sufficient quantity to complete the volume and homogenized. After 30 minutes, the solution was filtered and its absorbance measured at $760 \mathrm{~nm}$. Finally, the phenolic content was expressed as $\mathrm{mg}$ of tannic acid $/ \mathrm{mL}$ of solution, and total phenolics in $100 \mathrm{~g}$ of mucuna seed.

The phosphomolybdenum assay was performed in triplicate and the complex was prepared as described by Prieto, Pineda, and Aguilar (1999). A solution was prepared from $36 \mathrm{~mL}$ of ammonium molybdate, $28 \mathrm{~mL}$ of monobasic sodium phosphate, $20 \mathrm{~mL}$ of sulfuric acid solution and deionized water until achieving a $100 \mathrm{~mL}$ final volume. A standard solution of vitamin $\mathrm{C}$ was prepared at a concentration of $1 \mathrm{mg} / \mathrm{mL}$. A total of $3 \mathrm{~mL}$ of the prepared solution and $100 \mu \mathrm{L}$ of the extract or the standard was added to each flask. The flasks were incubated in hot water bath at $95{ }^{\circ} \mathrm{C}$ for 90 minutes. The flasks were then cooled to $25^{\circ} \mathrm{C}$, and stored in the absence of light before the absorbance measurements at $695 \mathrm{~nm}$. The antioxidant capacity of a $0.1 \mathrm{mg} / \mathrm{mL}$ levodopa (Sigma-Aldrich, St. Louis, USA) solution was compared to the antioxidant capacity of the $M$. pruriens acid extract, which was prepared by diluting $8.36 \mathrm{~g}$ of extract/10 $\mathrm{mL}$ of distilled water. The above-mentioned concentrations are equivalent, i.e., the concentration used in the $M$. pruriens solution is equivalent to a $0.1 \mathrm{mg} / \mathrm{mL}$ levodopa solution.

Measurement of the DPPH' radical scavenging activity was performed according to the method described by Brand-Williams, Cuvelier, and Berset (1995). The analyses were carried out in triplicate. To evaluate the antioxidant activity of the mucuna extract, this was put into contact with the DPPH ${ }^{*}$ stable radical at $6.10^{-5} \mathrm{mmol}$ (Sigma-Aldrich, St. Louis, USA) which was diluted in a $99.8 \%$ pure ethanol solution. More specifically, the reaction media comprised $20 \mu \mathrm{L}, 40 \mu \mathrm{L}, 60 \mu \mathrm{L}$ or $80 \mu \mathrm{L}$ of extract, sufficient water to obtain a $500 \mu \mathrm{L}$ volume, and $2.5 \mathrm{~mL}$ of $\mathrm{DPPH}^{\circ}$. The measurement of the $\mathrm{DPPH}^{*}$ radical reduction was performed by continuously monitoring of the decline in its absorbance at $515 \mathrm{~nm}$ for two hours, until reaching stable values of absorption. After several tests using standard antioxidants with different kinetic behavior, such as $\alpha$-tocopherol, butylated hydroxyanisole (BHA), gallic acid, quercetin and vitamin $\mathrm{C}$, a standard reading time of one hour (time required for the substances under assay to be oxidized) was adopted.

In the $\mathrm{DPPH}^{\circ}$ reduction assay, the results were expressed by means of the $\mathrm{EC}_{50}$, which corresponds to the minimal antioxidant concentration necessary for the $\mathrm{DPPH}^{*}$ to be reduced by $50 \%$. Another way to express the results is the anti-radical power (ARP), which expresses the inverse relationship of $\mathrm{EC}_{50}$ (Arbos, 2004). In our study, the $\mathrm{EC}_{50}$ values were calculated by linear regression of plots, where the $\mathrm{x}$-axis corresponds to the antioxidant concentration in $\mathrm{mg} / \mathrm{mL}$, and the $\mathrm{y}$-axis represents the average percentage of its antioxidant activity. This analysis was performed by using the software Excel 2007 (Microsoft Co.)

The assay of the $\mathrm{ABTS}^{-+}$radical formation was performed as described by Kuskoski et al. (2005), based on the authors Re et al., (1999) and Rice Evans and Miller (1994), with modifications. A cationic solution of ABTS ${ }^{+}$ (Sigma-Aldrich, St. Louis, USA) was prepared by mixing equal parts $(\mathrm{v} / \mathrm{v})$ of $\mathrm{ABTS}^{\circ+} 7.0 \mathrm{mM}$ and potassium persulfate $2.45 \mathrm{mM}$. This solution reacted for 12 hours at room temperature and in the absence of light. Subsequently, the mixture was added with an ethanol solution until its absorbance reached a value between $0.700( \pm 0.1)$ and $0.754 \mathrm{~nm}$. After seven minutes, the sample absorbance reading (at room temperature) was taken on a spectrophotometer at $734 \mathrm{~nm}$. As standard for this assay, 1.5 mM Trolox, i.e., 
6-hydroxy-2,5,7,8-tetrametil chrome-2-carboxylic acid (Sigma-Aldrich, St. Louis, USA) was used. Both of the antioxidant assays were carried out in triplicate.

To establish the correlation between the results obtained with $\mathrm{DPPH}^{\cdot}$ and $\mathrm{ABTS}^{\cdot+}$ methods multiple linear regression was applied. The following statistical parameters were generated: $n$ (the number of observations), $r$ (the regression coefficient), $s$ (the standard error of estimation) and $F$ (the calculated value of $F$-test). Statistical analysis was performed using STATISTICA 7.0 software (StatSoft, USA).

\section{RESULTS AND DISCUSSION}

The extract of mucuna presented a high yield, namely $5.4 \mathrm{~g}$ of extract $/ 10 \mathrm{~g}$ of the seed powder, with each gram of extract containing $120 \mathrm{mg}$ of levodopa (Figure 1). Figure 2 shows the chromatogram of the levodopa standard which represents $6.48 \%$. This value is higher than those cited by Chikagwa-Malunga et al. (2009) which were within the range 4.0 to $6.0 \%$, and also that reported by Prakash and Tewari (1999), which ranged from 3.6\% to $4.2 \%$. On the other hand, it is very similar to that reported by Vadivel and Janaradhanan (2000), which ranged from $6.7 \%$ to $7 \%$ The difference between our findings and other authors' results can be attributed to different genetic composition of the plants, locale of harvesting, maturity stage, and method of obtaining the extract (Eilittä et al., 2000).

Phenolic compounds are known for their high antioxidant power. This feature has been attributed to their capacity of reducing oxides, which play an important role in the adsorption or neutralization of free radicals (Basile et al., 2005). The total phenolic content observed in the acid extract of M. pruriens was $24 \pm 0.2 \mathrm{~g} / 100 \mathrm{~g}$ of extract, which corresponds to $6.48 \mathrm{~g}$ of total phenolics in $100 \mathrm{~g}$ of mucuna seed. This data was generated from the calibration curve made with tannic acid, which presented the following associated equation: $\mathrm{y}=0.4025 \mathrm{x}+0.0417$ $\left(\mathrm{R}^{2}=0.9996\right)$. These results are close to the levels of phenolic compounds found by Siddhuraju and Becker (2005), namely $5.65 \mathrm{~g} \%$, in the seed of $M$. pruriens and also the content presented by Adebowale, Adeyemi and Oshodi (2005) in this same species, who found $7.75 \pm 0.02 \mathrm{~g}$ per $100 \mathrm{~g}$ of dry seeds.

The antioxidant activity of a plant extract is dependent on the concentration of antioxidant substances in the plant, on the solvent used for extraction and on its form of preparation. In this trial, the assay of phosphomolybdenum complex reduction was selected due to factors such as the fact that it is a low cost established methodology with easy handling. In addition, Prieto, Pineda, and Aguilar (1999) reported that the assay can be carried out with different solvents, being suited for evaluation of extracts and highly capable of assessing antioxidant activity, especially for substances containing alpha-tocopherol and other powerful antioxidants. The analysis of the phosphomolybdenum complex reduction assay results was done through a calibration curve that provided the equation $\mathrm{y}=8.1102 \mathrm{x}+$ $0.1005\left(\mathrm{R}^{2}=0.9803\right)$. The reducing activity of the extract was expressed in vitamin $C$ equivalents, a substance recognized by its high antioxidant power (Van Dujin, Van

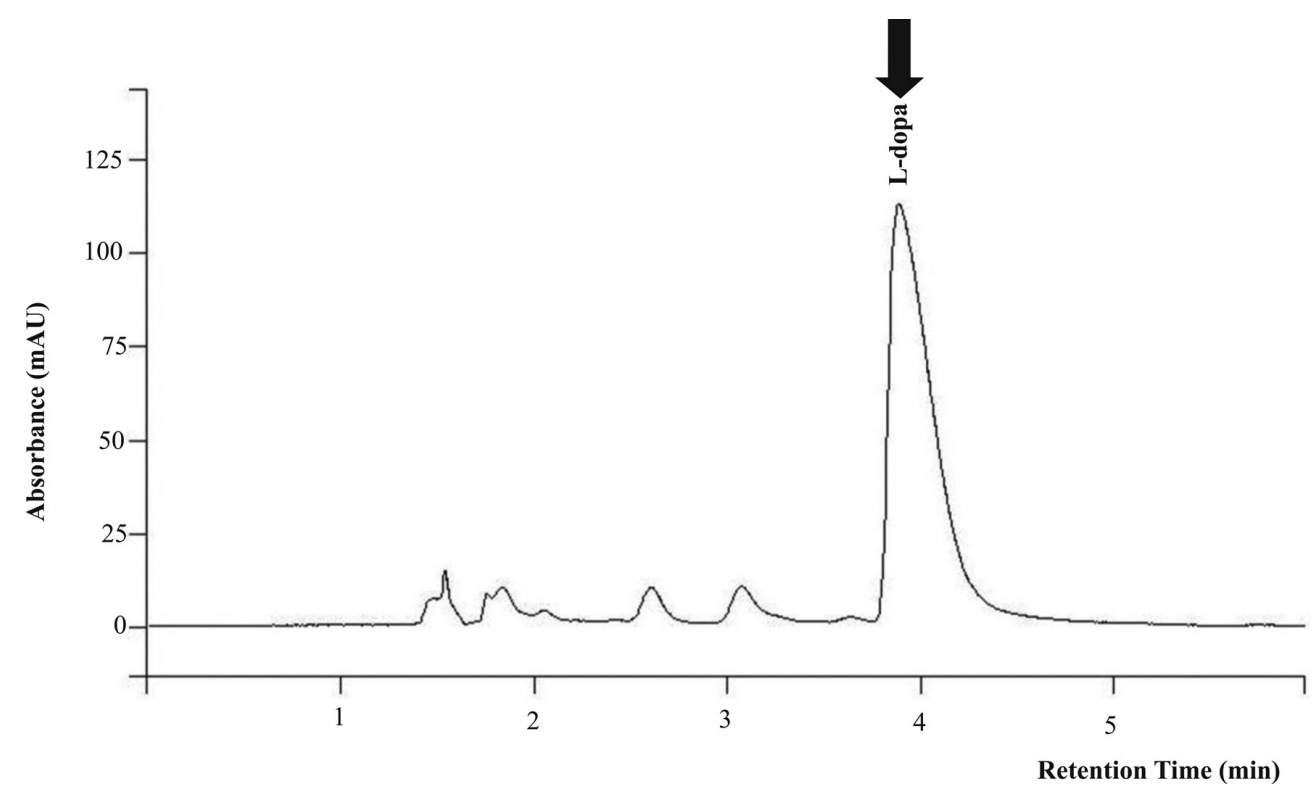

FIGURE 1 - Chromatogram of the acid extract of Mucuna pruriens seeds obtained by high-performance liquid chromatography. The highest peak indicates the presence of levodopa. 


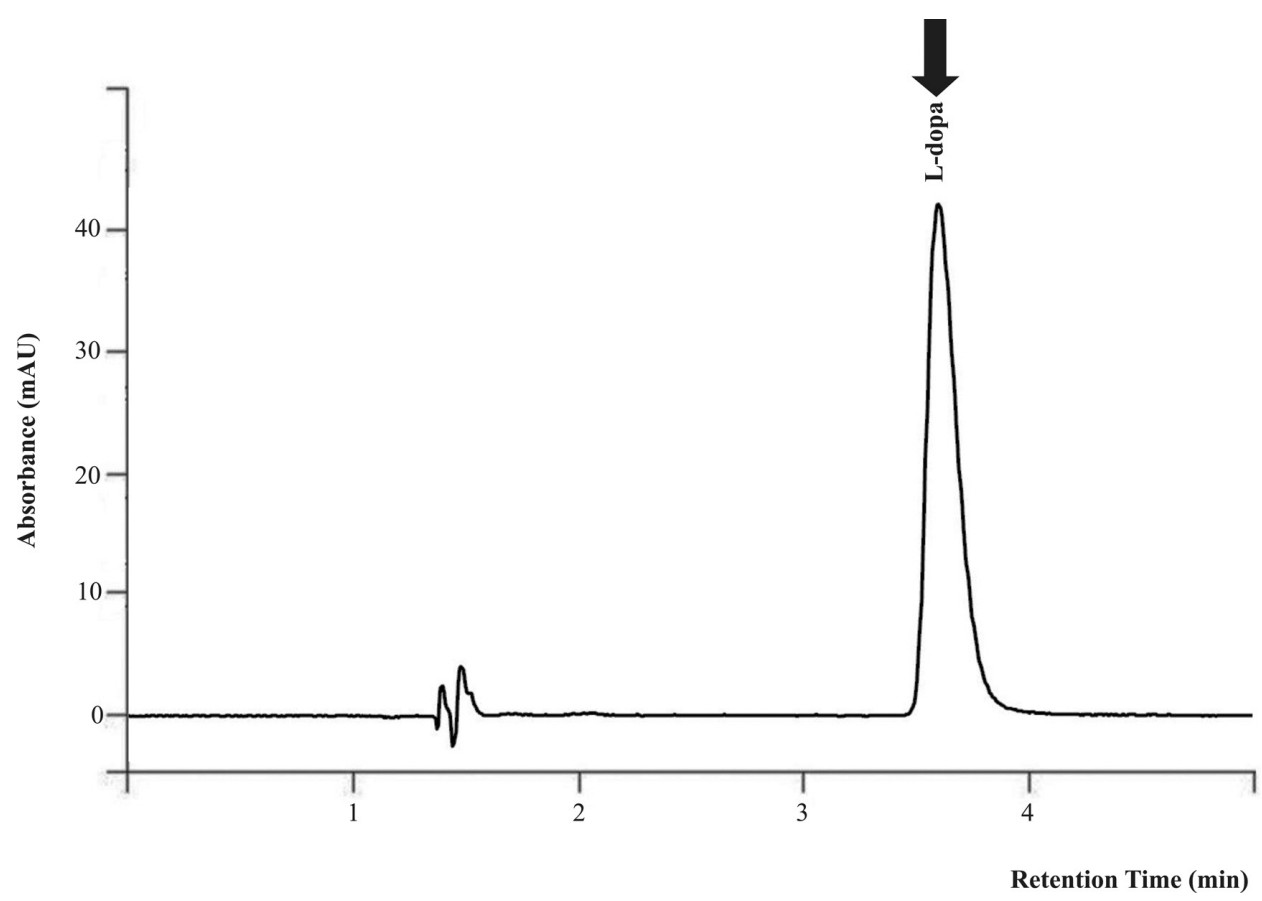

FIGURE 2 - Levodopa standard chromatogram obtained by high-performance liquid chromatography. The highest peak indicates the presence of levodopa.

Der Zee, Van Der Broek, 2002). The result found for the analyzed compounds was $0.361 \pm 0.02 \mathrm{mg}$ of vitamin $\mathrm{C}$ per milligram of extract and $3.35 \pm 0.02 \mathrm{mg}$ of vitamin $\mathrm{C}$ per mg of levodopa. Thus, it can be concluded that the extract has lower antioxidant activity than vitamin C. However, levodopa has antioxidant activity approximately three-fold higher than vitamin $\mathrm{C}$, or ten-fold higher than the obtained extract.

The various methods for measuring antioxidant activity differ in their reaction mechanisms, the target substance on which they act, the conditions under which they are carried out and the way in which results are expressed. These methods are used in different areas such as physiology, pharmacology, nutrition and food science, which renders it difficult to select the most appropriate method and to provide the correct interpretation of results. Therefore, in this study, well known low cost methods which are easy to perform were used.

The DPPH ${ }^{\cdot}$ radical scavenging method was chosen because it is simple, fast and sensitive. Increasing concentrations of the freeze-dried extract of Mucuna pruriens $(0.013,0.027,0.040,0.053 \mathrm{mg} / \mathrm{mL})$ were subjected to reaction with $\mathrm{DPPH}^{\circ}$. For each concentration tested, a reaction kinetic was built by means of a plot, which was associated with the following equation: $y=-1502.6+x 102.5$ $\left(\mathrm{R}^{2}=0.9875\right)$. This equation was used as the basis for the calculation of $\mathrm{EC}_{50}$. The antioxidant activity of levodopa alone was also evaluated. Increasing concentrations of levodopa (0.002, 0.004, 0.006 and $0.008 \mathrm{mg} / \mathrm{mL})$, which proved to be proportional to the concentration of levodopa present in the extract of mucuna (Figure 1), were tested. The results are shown in Table I.

TABLE I - EC $_{50}$ values and anti-radical power (ARP) of selected antioxidant substances, $M$. pruriens black seeds acid extract and levodopa standard

\begin{tabular}{lcc}
\hline Antioxidant Substance & $\mathrm{EC}_{50}(\mathrm{mg} / \mathrm{mL})$ & $\mathrm{ARP}$ \\
\hline BHA & 0.47 & 2.11 \\
Vitamin C & 0.27 & 3.70 \\
Alpha-tocopherol & 0.26 & 3.85 \\
Quercetin & 0.09 & 10.95 \\
Gallic acid & 0.08 & 12.72 \\
Acid extract of Mucuna pruriens & 0.035 & 28.62 \\
Levodopa standard & 0.030 & 33.09 \\
\hline
\end{tabular}

The ARP values observed for ascorbic acid, alphatocopherol, gallic acid and BHA in the present study are in line with the results obtained by Brand-Williams, Cuvelier, and Berset (1995), while the value of the ARP for the quercetin is similar to that found by Peyrat-Maillard, Bonnely and Berset (2000). Comparing the values of ARP of the freeze-dried Mucuna pruriens extract to the values of ARP of the other substances tested (Table I), revealed that the 
extract had the highest antioxidant capacity, except from the levodopa standard. Our results are in line with those obtained by Rajeshwar et al. (2005), who claimed that the methanolic extract of $M$. pruriens exhibits antioxidant activity (as evaluated by the DPPH ${ }^{*}$ method) which is high compared to different substances such as BHT, ascorbic acid, quercetin and alpha-tocopherol.

Another method often used to determine the ability of an antioxidant to scavenge free radicals is the ABTS ${ }^{+}$ method, which presents high sensitivity, besides being practical, fast and using a very stable reactant (Arnao, 2000).

Figure 3 shows the calibration curve for the ABTS ${ }^{\cdot+}$ method. Figure 4 shows the comparison between the levodopa standard kinetic behavior and the M. pruriens extract kinetic behavior, using Trolox as standard. On the basis of the equation associated to each reactant, it can be observed that for a $50 \% \mathrm{ABTS}^{++}$reduction, $45.43 \mathrm{mg}$ of Trolox, or $0.816 \mathrm{mg}$ of levodopa or $12.714 \mathrm{mg}$ of $M$. pruriens extract, was required. Thus, both levodopa and the extract had greater antioxidant activity than that of Trolox. In addition, the levodopa standard had superior antioxidant activity when compared to that of the extract (about 15.6-fold higher).

The two most widely used methods for the evaluation of antioxidant activity are the $\mathrm{ABTS}^{\circ+}$ and the $\mathrm{DPPH}^{\circ}$ methods. Both present excellent stability in certain assay conditions but also show several important differences in their response to antioxidants and manipulation. The superiority of the ABTS ${ }^{+}$assay over $\mathrm{DPPH}^{\cdot}$ is explained because $\mathrm{ABTS}^{++}$is operable over a wide range of
$\mathrm{pH}$, inexpensive and more rapid than that of the $\mathrm{DPPH}^{\circ}$ assay. Another important difference is that $\mathrm{ABTS}^{++}$can be solubilized in aqueous and in organic media, in which the antioxidant activity can be measured due to the hydrophilic and lipophilic nature of the compounds in samples. In contrast, $\mathrm{DPPH}^{*}$ can only be dissolved in alcoholic media (Kuskoski et al., 2005). The determination of ABTS ${ }^{\cdot+}$ measures the total amount of an antioxidant standard consumed (Trolox), while the DPPH' method measures the speed of radical consumption. A linear correlation between DPPH ${ }^{*}$ radical scavenging activity and polyphenolic contents has been reported in different vegetables (Iqbal; Bhanger; Anwar, 2005). Leong and Shui (2002) observed that the antioxidant potential measured through the DPPH and the $\mathrm{ABTS}^{\circ+}$ assays was very similar for 11 out of 27 fruits analyzed. For six fruits, the difference between the results obtained by the two methods was less than $20 \%$ whereas for nine fruits, it was greater than $50 \%$.

A strong correlation was observed between the antioxidant activity as measured by using the $\mathrm{ABTS}^{\cdot+}$ and the $\mathrm{DPPH}^{\circ}$ antioxidant assays $\left(\mathrm{R}^{2}=0.995\right)$, which could be related to the presence of anthocyanins. This is confirmed by the fact that this correlation was much weaker when the comparison was made between samples that do not contain polyphenols $\left(\mathrm{R}^{2}=0.599\right)$ (Thaipong et al., 2006). Mucuna pruriens extract had a high content of phenolic compounds, which are soluble in hydroalcoholic media, explaining the high correlation $\left(r=0.97 ; \mathrm{R}^{2}=0.93\right)$ between the results generated by using the $\mathrm{DPPH}^{\cdot}$ and $\mathrm{ABTS}^{-+}$ methods in this work (Table II).

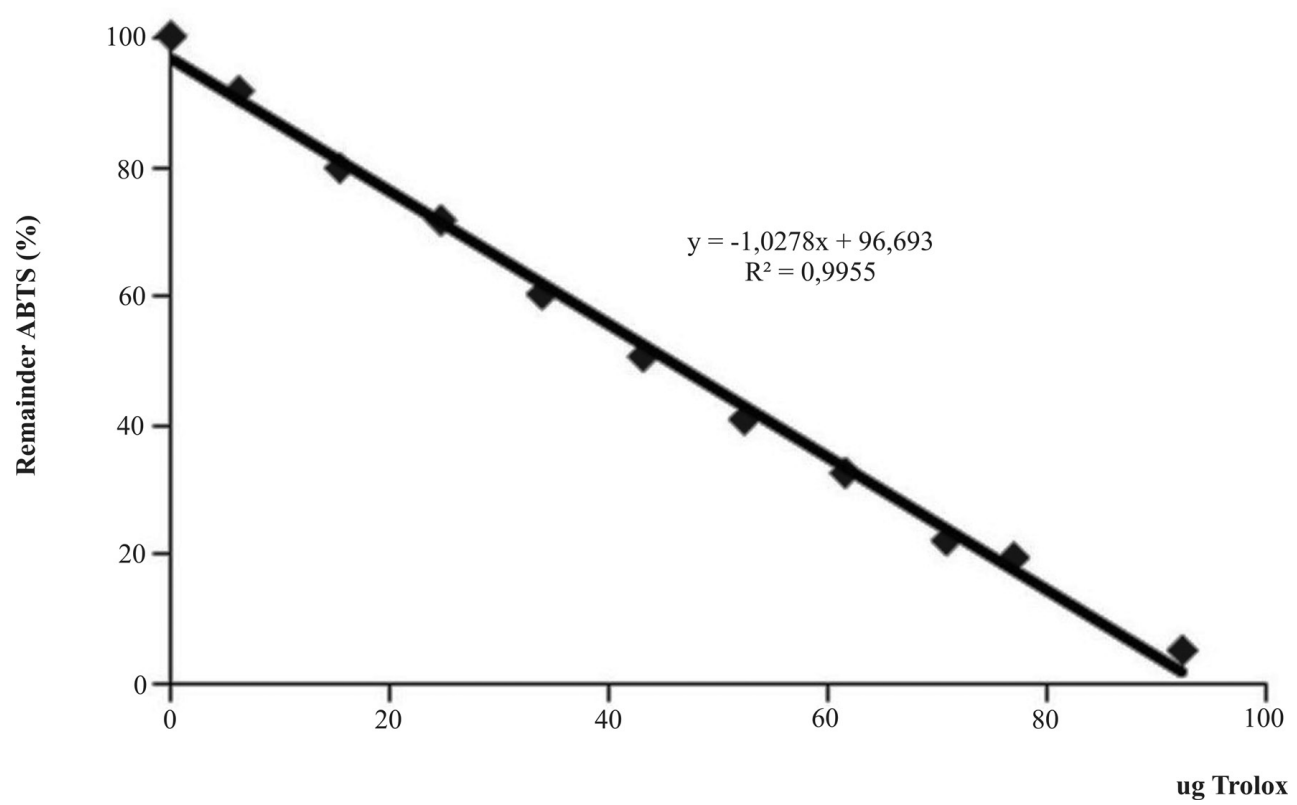

FIGURE 3 - Calibration curve for the $\mathrm{ABTS}^{\cdot+}$ method as generated by measuring the absorbance of the reaction medium at $734 \mathrm{~nm}$. Trolox was used as standard. 


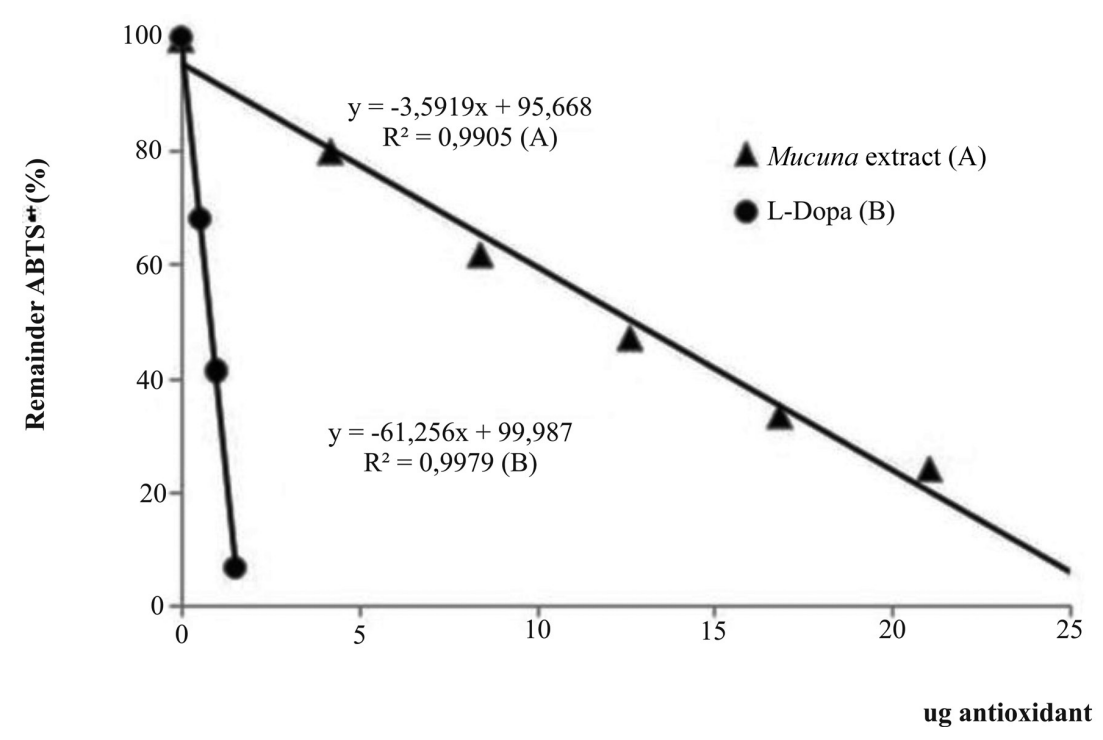

FIGURE 4 - Effect of standard levodopa and M. pruriens extract concentrations on the inhibition of the ABTS ${ }^{\cdot+}$ radical.

TABLE II - Parameters for the correlation analysis between the results yielded by using the DPPH ${ }^{\bullet}$ and $\mathrm{ABTS}^{\cdot+}$ methods, as generated by using multiple linear regression

Regression Summary for Dependent Variable: ABTS $^{++}$(mucuna.sta)

$\mathrm{R}=.96772315 \mathrm{R}^{2}=.93648809$ Adjusted $\mathrm{R}^{2}=.93071428$

$\mathrm{F}(1.11)=162.20 \mathrm{p}<.00000$ Std.Error of estimate: 8.6390

\begin{tabular}{lcccccc} 
& Beta & Std.Err. of Beta & B & Std.Err. of B & t (11) & p-level \\
\hline Intercept & & & -32.9078 & 5.671074 & -5.80274 & 0.000119 \\
DPPH $^{\cdot}$ & 0.967723 & 0.075986 & 1.1552 & 0.090707 & 12.73561 & 0.000000 \\
\hline
\end{tabular}

Arnao (2000) and Thaipong et al. (2006) reported that the $\mathrm{DPPH}^{\cdot}$ and the $\mathrm{ABTS}^{\cdot+}$ assays showed similar results. The same authors observed that, when compared to all other substances evaluated, levodopa showed the highest antioxidant activity. In addition, the acid extract of M. pruriens presented a remarkable antioxidant activity, which was greater than all of the reference antioxidants assessed in the $\mathrm{DPPH}^{*}$ assay, except for quercetin and levodopa. There are no reports comparing the phosphomolybdenum assay to other antioxidant capacity assays (Ou et al., 2002; Vedana et al., 2008; Capitani et al., 2009). As described by Alonso et al. (2002), the complexity of this assay hampers this type of comparison.

Ozgen et al. (2006) reported that the differences found when two or more different methods are used to evaluate the antioxidant activity of plant products occur for two main reasons: firstly, each method provides only the estimated antioxidant capacity, according to the reaction time, the methodology used and the complexity of the kinetic reactions; secondly, the potential interaction between phenolic compounds in natural matrices may cause natural products to present a lower antioxidant activity when compared to isolated compounds. In addition, there are no methods capable of demonstrating the total antioxidant capacity of compounds with complex kinetics, like the natural compounds.

\section{CONCLUSION}

The acid extract of $M$. pruriens used in the present study had a high phenolic content, and consequently, marked antioxidant activity. This can be confirmed by comparing its antioxidant activity to that of vitamin C, BHA, Trolox, etc., as measured through the use of the $\mathrm{DPPH}^{\cdot}$ and $\mathrm{ABTS}^{\circ+}$ assays. Correlation of $93 \%$ was observed between the results obtained on the $\mathrm{DPPH}^{\cdot}$ and the $\mathrm{ABTS}^{\cdot+}$ antioxidant assays.

Currently, the reports on antioxidant activity evaluation fail to describe the substances that react in each test. The information reported comprises solely the diluents used and the indication of use (plant extracts, fruit juices, isolated substances, hydrophilic compounds etc.). 
In the light of the information contained in this report, it is possible to conclude that the M. pruriens grown in Brazil exhibits high antioxidant activity. Therefore, it is necessary to further investigate which compounds this plant contains along with their benefits and potential harm to human health.

\section{ACKNOWLEDGEMENTS}

The authors would like to thank the Fundacão Araucária de Apoio ao Desenvolvimento Cientifico e Tecnológico do Paraná for the financial support (Protocol 5257).

\section{REFERENCES}

ADEBOWALE, Y. A.; ADEYEMI, A.; OSHODI. A. A. Variability in the physicochemical, nutritional and antinutritional attributes of six Mucuna species. Food Chem., Barking, v.89, n.1, p.37-48, 2005.

ALONSO, A.M.; DOMINGUEZ, C.; GUILLEN, D.A.; BARROSO, C.G. Determination of antioxidant power of red and white wines by a new eletrochemical method and its correlation with polyphenolic content. J. Agric. Food Chem., Washington, v.50, n.11, p.3112-3115, 2002.

AMIN, K.M.Y.; KHAN, M.N.; ZILLUR-REHMAN, S.; KHAN, N.A.; Sexual function improving effect of Mucuna pruriens in sexually normal male rats. Fitoterapia, Milano, v.67, n.1, p.53-56, 1996.

ARBOS, K.A. Estudo do potencial antioxidante de vegetais da família Cruciferae de diferentes cultivos. Curitiba, 2004. 86 f. [Dissertação de Mestrado em Ciências Farmacêuticas. Setor de Ciências da Saúde. Universidade Federal do Paraná].

ARNAO, M.B. Some methodological problems in the determination of antioxidant activity using chromogen radicals: a practical case. Trends Food Sci. Technol., Philadelphia, v.11, n.11, p.419-421, 2000.

BRAND-WILLIAMS, W.; CUVELIER, M.E.; BERSET, C. Use of a free radical method to evaluate antioxidant activity. Lebenson Wiss Technol, Philadelphia, v.28, n.1, p.25-30, 1995.

BASILE, A., FERRARA, L., DEL POZZO, M., MELE, G., SORBO, S.; BASSI, P., MONTESANO, D. Antibacterial and antioxidant activities of ethanol extract from Paullinia cupana Mart. J. Ethnopharmacol. Philadelphia, v.102, n.1, p.32-36, 2005.
BROINIZI, P.R.B.; ANDRADE-WARTHA, E.R.S.; SILVA, A.M.O.; NOVOA, A.J.V.; TORRES, R.P.; AZEREDO, H.M.C.; ALVES, R.E.; MANCINI-FILHO, J. Avaliação da atividade antioxidante dos compostos fenólicos naturalmente presentes em subprodutos do pseudofruto de caju (Anacardium occidentale L.). Cienc. Tecnol. Aliment., Campinas, v.27, n.4, p.902-908, out-dez. 2007.

CAPITANI, C.D.; CARVALHO, A.C.L.; RIVELLI, D.P.; BARROS, S.B.M.; CASTRO, I.A. Evaluation of natural and synthetic compounds according to their antioxidant activity using a multivariate approach. Eur. J. Lipid Technol., Mittwoch, v.111, n.11, p.1090-1099, 2009

CHIKAGWA-MALUNGA, S.K.; ADESOGAN, A.T.; SOLLENBERGER, L.E.; BADINGA, L.K.; SZABO, N.J.; LITTELL, R.C. Nutritional characterization of Mucuna pruriens. 1. Effect of maturity on the nutritional quality of botanical fractions and the whole plant. Anim. Feed Sci. Technol., New York, v.148, n.1, p.34-50, 2009.

DHANASEKARAN, M.; THAKARAN, B.; MANYAM, B.V. Antiparkinson-drug - Mucuna pruriens shows antioxidant and metal chelating activity. Phytother. Res., London, v.22, n.1, p.6-11, 2008.

DIALLO, O.K; KANTE, S; MYHRMAN, R; SOUMAH, M; CISSÉ, N. Y; BERHE, T. Increasing farmer adoption of Mucuna pruriens as human food and animal feed in the republic of Guinea. In: INTERNATIONAL WORKSHOP ON FOOD AND FEED FROM MUCUNA, Proceedings. Tegucigalpa, 2000. Tegucigalpa, International Center for Information on Cover Crops (CIDICCO), 2002. p.60-72.

DOW CHEMICAL. WYSONG, D.V. Recovery of 3-(3,4-Dihydroxyphenyl-)-L-Alanine from velvet beans. Int. Cl260 A 519. U.S. PI 3,253,023. 24 may. 1966; 27 sept. 1963. Patented. U.S., n.311, p. 944, 27 sept. 1966.

EILITTÄ, M; BRESSANI, R; CAREW L.B; CARSKY, R.J; FLORES, M; GILBERT, R; HUYCK, L; ST LAURENT, L; SZABO, N.J. Mucuna as a food and feed crop. In: International Workshop on Food and Feed from Mucuna. Proceedings. Tegucigalpa, 2000. Tegucigalpa: International Center for Information on Cover Crops (CIDICCO), 2002. p.18-47.

HOUGHTON, P.J.; HOWES, M.J. Natural products and derivates affecting neurotransmission relevant to Alzheimer's and Parkinson's disease. NeuroSignals., Basel, v.14, n.1-2, p.6-22, 2005. 
HUSSIAN, G.; MANYAM, B.V. Mucuna pruriens proves more effective than L-Dopa in Parkinson's disease animal model. Phytother. Res., London, v.11, n.6, p.419-423, 1997.

IQBAL, S.; BHANGER, M. I; ANWAR, F. Antioxidant properties and components of some commercially available varieties of rice bran in Pakistan. Food Chem., Barking, v.93, n.2, p.265-272, 2005.

KAVITHA, C.; VADIVEL, E. In vitro production of L.DOPA from Mucuna pruriens (L.) DC. In: KESHAVACHANDRAN, R.; NAZEEM, P.A.; GIRIJA, D.; JOHN, P.S.; PETER, K.V. Recent trend in horticultural biotechnology. New Delhi: New India Publishing Agency, 2007. p.395-401.

KRISHNAIAH, D.; SARBATLY, R.; NITHYANANDAM, R. A review of the antioxidant potential of medicinal plant species. Food Bioprod. Process, Melbourne, 2010 Available at: <http://www.sciencedirect.com/science/ journal/09603085>. Accessed on: 19 abr. 2011.

KUSKOSKI, M.; ASUERO, A.G.; TRONCOSO, A.M.; MANCINI-FILHO, J.; FETT, R. Aplicación de diversos métodos químicos para determinar actividad antioxidante em pulpa de frutos. Cienc. Tecnol. Aliment., Campinas, v.25, n.4, p.726-732, 2005.

LEONG, L. P.; SHUI, G. An investigation of antioxidant capacity of fruits in Singapore markets. Food Chem., Barking, v.76, n.1, p.69-75, 2002.

LIEU, C. A.; KUNSELMAN, A.R.; MANYAM, B.V.; VENKITESWARAN, K.; SUBRAMANIAN, T. A water extract of Mucuna pruriens provides long-term amelioration of parkinsonism with reduced risk for dyskinesias. Parkinsonism Relat. Disord., Devon, v.16, n.7, p.458-465, 2010.

MANYAM, B.V. Paralysis agitans and levodopa in "Ayurveda": ancient Indian medical treatise. Mov. Disord., Danvers, v.5, n.1, p.47-48, 1990.

MANYAM, B.V.; DHANASEKARAN, M.; HARE, T.A. Neuroprotective effects of the antiparkinson drug Mucuna pruriens. Phytother. Res., London, v.18, n.9, p.706-712. 2004.

MILLER, D.M.; BUETTNER, G.R.; AUST, S.D. Transition metals as catalysts of "autoxidation" reactions. Free Radic. Biol. Med., Philadelphia, v.8, n.1, p.95-108. 1990.
OU, B.; HUANG, D.; HAMPSCH-WOODIL, M.; FLANAGAN, J.A.; DEEMER. E.K. Analysis of antioxidant activities of common vegetables employing oxygen radical absorbance capacity (ORAC) and ferric reducing antioxidant power (FRAP) assays: A comparative study. J. Agric. Food Chem., Washington, v.50, n.11, p.3122-3128, 2002.

OZGEN, M.; REESE, R.N.; TULIO JR, A.Z.; SCHEERENS, J.C.; MILLER, A.R. Modified 2,2-Azino-bis-3ethylbenzothiazoline-6-sulfonic Acid (ABTS) method to measureantioxidant capacity of selected small fruits and comparison to ferric reducing antioxidantpower (FRAP) and 2,2-diphenil-1-pycrylhydrazyl (DPPH) methods. $J$. Agric. Food Chem., Washington, v.54, n.4, p.1151-1157, 2006.

PEYRAT-MAILLARD, M.N.; BONNELY, S.; BERSET, C. Determination of antioxidant activity of phenolic compounds by coulometer detection. Talanta, Philadelphia, v.51, n.4, p.709-716, 2000.

PÓVOA FILHO, H. Radicais livres em distúrbios neurológicos e no envelhecimento. In: PÓVOA, L.G. (Ed.) Radicais livres em patologia humana. Rio de Janeiro: Imago,1995. p.163-181.

PRAKASH, D.; TEWARI, S.K. Variation on L-Dopa contents in Mucuna species. J. Med. Arom. Plant Sci., India, v.21, [s.n], p.343-346, 1999.

PRIETO, P.; PINEDA, M.; AGUILAR, M. Spectrophotometric quantitation of antioxidant capacity trough the formation of a phosphomolybdenum complex: specific application to the determination of vitamin E. Anal. Biochem., New York, v.269. n.2, p.337-341, 1999.

RAJESHWAR, Y.; KUMAR, S.; GUPTA, M.; MAZUMDER, U.K. Studies on in vitro antioxidant activities of methanol extract of Mucuna pruriens (Fabaceae) seeds. Eur. Bull. Drug Res., Firenze, v.13, n.1, p31-39, 2005.

RE, R.; PELLEGRINI, N.; PROTEGGENTE, A.; PANNALA, A.; YANG, M.; RICE-EVANS, C. Antioxidant activity applying an improved ABTS radical cation decolorization assay. Free Radic. Biol. Med., New York, v.26, n.9/10, p.1231-1237, 1999.

RICE-EVANS, C.; MILLER, N.J. Total antioxidant status in plasma and body fluids. Methods Enzymol., New York, v.234, [s.n], p.279-293, 1994. 
ROGERS, S.; WITZ, G.; ANWAR, M.; HIATT, M.; HEGYI, T. Antioxidant capacity and oxygen radical disease in the preterm new born. Arch. Pediatr. Adolesc. Med., Chicago, v.154, n.7, p.544-548, 2000.

SATHIYANARAYANAN, L.; ARULMOZHI, S. Mucuna pruriens Linn - a comprehensive review. Pharmacog. Rev., Mumbai, v.1, n. 1, p. 157-162, 2007.

SIDDHURAJU, P.; VIJAYAKUMARI, K.; JANARDHANAN, $\mathrm{K}$. Chemical composition and protein quality of the littleknown legume, velvet bean (Mucuna pruriens (L.) DC). J. Agric. Food Chem., Washington, v.44, n.9, p.2636-2641, 1996.

SIDDHURAJU, P.; BECKER, K. Rapid reverse-phase high performance liquid cromatographic method for quantification of L-Dopa (L-3,4-dihydroxyphenylalanine), non-methylated and methylated tetrahydroisoquinoline compounds of Mucuna beans. Food Chem., Barking, v.72, n.3, p.389-394, 2001.

SIDDHURAJU, P.; BECKER, K. Nutritional and antinutritional composition, in vitro amino acid availability, starch digestibility and predicted glycemic index of differentially processed mucuna beans (Mucuna pruriens var. utilis): an under-utilised legume. Food Chem., Barking, v.91, n.2, p.275-286, 2005.

SWAIN, T.; HILLIS, W.E. The phenolic constituints of Prunus domestica I. The quantitative analysis of phenolic constituents. J. Sci. Food Agric., New York, v.10, n.1, p.63-68, 1959.

SZABO, N.J.; TEBBETT, I.R. The chemistry and toxicity of Mucuna species. In: International Workshop Food and Feed from Mucuna, 2002. In: Proceedings... Tegucigalpa, Honduras: Judson College, 2002. p. 120-141.

THAIPONG, K.; BOONPRAKOB, U.; CROSBY, K.; CISNEROS-ZEVALLOS, L.; BYRNE, D. H. Comparison of ABTS, DPPH, FRAP, and ORAC assays for estimating antioxidant activity from guava fruit extracts. J. Food Compos. Anal., San Diego, v.19, n.6-7, p.669-675, 2006.
THARAKAN, B.; DHANASEKARAN, M.; MIZE-BERGE, J.; MANYAM, B.V. Anti-Parkinson botanical Mucuna pruriens preventes levodopa -induced plasmid and genomic DNA damage. Phytother. Res., London, v.21, n.12, p.1124-1126, 2007.

TRIPATHI, Y.B.; UPADHYAY, A.K. Antioxidant property of Mucuna pruriens Linn. Curr. Sci., Bangalore, v.80, n.11, p.1377-1378, 2001.

TRIPATHI, Y.B.; UPADHYAY, A.K Effect of the alcohol extract of the seeds of Mucuna pruriens on free radicals and oxidative stress in albino rats. Phytother. Res., London, v.16, n.6, p.534-538, 2002.

VALKO, M.; RHODES, C.J.; MONCOL, J.; IZAKOVIC, M.; MAZUR, M. Free radicals, metals and antioxidants in oxidative-stress-induced cancer. Chem. Biol. Interact., Amsterdam, v.160, n.1, p.1-40. 2006.

VAN DUJIN, M.M.; VAN DER ZEE, J.; VAN DER BROEK, P.J. Analysis of transmembrane redox reactions: interaction of intra- and extracellular ascorbate species. Methods Enzymol., New York, v.352, [s.n], p.268-279, 2002.

VADIVEL, V.; JANARDHANAN, K. Nutritional and antinutritional composition of velvet bean: An underutilized food legume in South India. Int. J. Food Sci. Nutr., Basingstoke, v.51, n.4, p.279-287. 2000.

VADIVEL, V.; PUGALENTHI, M. Removal of antinutritional/ toxic substances and improvement in the protein digestibility of velvet bean seeds during various processing methods $J$. Food Sci. Technol., India, v.45. p.242-246. 2008.

VEDANA, M. I. S.; ZIEMER, C.; MIGUEL, O. G.; PORTELLA, A.C.; CÂNDIDO, L. M. B. Efeito de processamento na atividade antioxidante da uva. Alim. Nutr., Araraquara, v.19, n.2, p.123-129. 2008

Received for publication on $11^{\text {th }}$ November 2010 Accepted for publication on $14^{\text {th }}$ April 2011 